\title{
The Phenomenology of Alcoholism Labelling: the Internalization of the Label in Treated Alcoholics in Croatia
}

\author{
Erik Brezovec ${ }^{1}$, Zoran Zoričić2 ${ }^{2}$ Marija Klarić Markus³ \\ ${ }^{1}$ University Department of Croatian Studies, Zagreb, Croatia, ${ }^{2}$ University Department of \\ Psychiatry at the University Hospital Sestre milosrdnice Zagreb, Croatia, ${ }^{3}$ Ministry of the \\ Interior of the Republic of Croatia, Zagreb, Croatia
}

\begin{abstract}
This research paper originates from the phenomenological analysis of labelling alcoholism and its individual internalization. Using a qualitative method of focus groups, the meaning and experience of an alcoholic label in Croatia was researched. Using a model of the response to treatment, it can be discussed how the significance of the label is realized in different contextual links. In the model, the relationship between personal choice and an encouraging environment, personal choice and a conformist environment and a lack of personal choice with a negative prefix on the surrounding factors are discussed. The basic starting point of the research paper lies in the hypotheses of the existence of par excellance reality, the reality of everyday life and the forms that are tied to it. However, an individual situationally estimates the significance of those forms and characteristically self-internalizes them. Even though it has a phenomenological analysis in its roots, the research paper characterises the duality of structure and action regarding the label of alcoholism. The supposed reality of everyday life and its relationship with alcoholism are not enough for social functionality of the alcoholic label. Subjectification, that is, internalization of the label is needed in order to achieve purpose and meaning.
\end{abstract}

Key words: label, alcoholism, treated alcoholics, Croatia, phenomenology

Copyright (C) 2019 KBCSM, Zagreb

e-mail: alcoholism.kbcsm@gmail.com•www.http://apr.kbcsm.hr

\section{Introduction}

The goal of this research paper is to describe the experience and significance of accepting the alcoholic label in Croatia. Namely, alcohol as a substance can be approached with two interpersonally connect-

Correspondence to: Erik Brezovec, mag. soc et mag. educ. soc., University Department of Croatian Studies Borongajska cesta 83 d, 10000 Zagreb, Croatia E-mail: ebrezovec@hrstud.hr ed origins. The first approach treats alcohol as a substance that potentially leads to alcoholism as an illness. Following the World Health Organization's definition of alcohol, an alcoholic is a patient who, because of an excessive use of alcoholic beverages, experiences physical and psychological addiction, health problems and potential social disorders. With this approach the focus is mainly put on the damaging effects alcohol 
can cause for an individual and society. Biomedical sciences approach alcohol firstly on the foundation of its characteristics and its relationship with the consumer. The second starting point is the one that gives alcohol and alcoholism a cultural dimension. Alcohol, in this context, with its potential damaging properties, can be observed as an integrative factor of the everyday life ritual. In this research paper special focus will be put on the synthesis of these approaches and starting points. The main research question of the research paper is: in which ways is the alcoholic label internalized and what meaning is given to it with an individual affected by it inside Croatian society? The answer to this issue is located in the use of the phenomenological approach as a protosociological discipline as well as the review and implementation of that approach in an empirical sense. In that sense, the phenomenology of alcohol consumption is shown in the first part of the research paper. Similarly, the terminal division between "consumption" and "usage" is elaborated on as to lessen the extent of the research. In the second part of the research paper theories that are rooted in phenomenology are put across. The third part of the research paper describes the methodology of the empirical part of the research paper and describes in greater detail the way of choosing participants and the process of garnering achievements for the research. In the upcoming chapter results of the research will be shown through the focus group method. The last part of the research paper will be dedicated to a debate in which the obtained findings will be compared to the theoretical limits given and elaborated on in the previous chapters

\section{The Phenomenology of Alcohol Consumption}

Phenomenology as a protosociological discipline but also as a relevant empirical method, is forced upon as a necessity in understanding the internalization of the significance of alcohol usage or alcohol abuse in a microcontextual sense. Micro sociological analysis of alcohol usage is focusing it own method to the understanding of meaning that alcohol usage has for the individual. It also holds the importance at the correlation of alcohol, alcoholism and identity formation of individual in respect to the collective life. For that matter identity as a category is defined as a source of meaning and sense of one specific social, national, cultural context. The meaning that person has toward alcohol usage and its role for the interaction of everyday life is investigated in the matter of creation of label that individual with excessive drinking gets from the society. This kind of label (in the sense of the paper) is considered in the sense of stigma. Stigma is a distinction of what person is and what society wants this person to be. Phenomenology provides us with the tool of looking on label (stigma) through the eyes of the stigmatized. How does this label help alcoholic in gaining the social certainty.

Namely, alcohol in this context is observed through cultural hypotheses. Alcohol in Croatian society is presented as one of the key elements of integration and ritual patterns of everyday life. As such, it can be observed as an objective thing in the reality of everyday life. In the research paper the question of subjective, but also the intersubjective realization of alcohol in everyday life is asked. In other words, an individual invents 
their own perception of the significance of alcohol in everyday life, but in the same way they participate in the patterns specific for alcohol tolerance in an interactional sense. The cohesiveness of the subjective and interactive makes up the everyday derivative of alcohol possible and sensible for the individual, but also for the cultural identity in a larger meaning (in this case, Croatian society).

Furthermore, objectification of the subjective meaning of alcohol is questioned. Namely, in that sense, specific ways of labelling alcohol are set in Croatian society. Alcohol is characterised by the symbolism which is a part of the ritual derivatives of everyday life. In that context, alcohol is one of the symbols of certain everyday rituals. An example for what has been mentioned can be found in everyday life when alcohol is mentioned within the borders of a certain occasion or celebration. In a large number of cases that same mention marks joy and waiting for an event; partially because of the properties of alcohol, partially because of the manifestation of solidarity as opposed to the collective in Croatian society. The objective entry of alcohol as a symbol inside the ritual of everyday life marks certain rules of the everyday phenomenon. However, the internalization of its worth alludes to the subjectification of its meaning. The individual internalizes the sensibility of that situation and interprets it on the foundation of their own experience. The category of internalization of sensibility is important for the phenomenology of alcohol, but also alcoholism because it's exactly sensibility the key component to observing alcohol in a cultural context. Alcohol is culturally justified as long as it maintains individual and collective sensibility as one of the symbols. If nothing can be justified, social pathology comes up which is solved through processes of institutionalization of the individual with the aim of bringing them back to ritual sensibility.

For social and rituals sensibility to be ensured, society develops control mechanisms and sanctions for approaching these patterns. According to what has been mentioned, it is important to add the characteristic of alcohol in the spirit of realizing a person as a social being. Becoming a person is achieved through a complicated process of creating sentience and self-consciousness, reflection towards others and opinions of such. Alcohol is a complex cultural phenomenon which a person learns about through the processes of primary and secondary socialization. In those processes the person gains standardization of alcohol in their social life. Standardizations in phenomenology are referred to typical behavioural patterns in typical situations to someone or something. In other words, standardizations are not individual, but they belong to a mutual perception of reality of a certain collective. The means of conducting subjective reality on the basis of standardization of alcohol, therefore, they determine the degree of alcohol's deviant nature and the phenomenon of alcoholism. Similarly, it is important to enunciate how internalization of the standardization of alcohol is mainly dependent on the individual's situational experience. The situation in this case is understood as a structurally limited field of the individual's actions. The internalization of situational experience which is, in the end, individual, determines the phenomenology of alcohol and alcoholism. From this perspective, alcoholism can be defined as an illness which can be characterized as a loss of typical sense of reality of everyday life in regards to alcohol as one of its symptoms. Alcoholism in a phenomenological sense is 
presented as a discrepancy of individual reality and reality of everyday life. In this research paper the original question of the significance of the alcoholic label in treated alcoholics is asked. In which ways the significance of the label unwinds, what factors were crucial in the treatment's success and what the reflection on the reality of everyday life after treatment is like. In the same way, the question of realization and the means of solving the mentioned discrepancy is asked.

Before the transition to methodological and theoretical hypotheses of the research paper it is important to note that phenomenology of alcoholism, which is also a part of this analysis, is not characterised by drinking, but the ways and conditions under which the drinking has taken place. In itself, alcoholism is not just a biological and a medicinal phenomenon. It is socio-culturally defined in its performance and the ways of assigning the label [11].

\section{Participants and methods}

The main aim of this research is to explore the experience and the significance of the alcoholism label for treated alcoholics. Firstly, the research question focuses on revealing the meaning of social factors in the decision for treatment. The question at hand is; in which ways is the addict label internalized and in which ways does a person decide to treat their alcohol addiction? Is it a personal choice or a social coercion?

With the goal of answering these questions a qualitative research has been conducted in the aspect of a focus group with treated alcoholics of the Clinical Hospital Centre of the Charitable Sister in Zagreb. This research paper is based on the phenomenological approach with the aim of finding meaning through experiences of the focus group's members. The group was, because of the topic's sensitivity, conducted with two moderators under controlled conditions. The focus group was thematically divided into conversation about the time period of discovering the problem, the decision of going to treatment, reflecting on the patients' previous state through their current experience, the relation of society towards today's rehabilitated alcoholics. In the same way, in the confines of the focus group the question of the organizations' significance and the significance of the clubs of treated alcoholics in successful abstinence was asked. The answers to the questions were gotten through semi-structured conversation with the participants and through the moderator's notes during the research. All of the participants voluntarily entered the focus group and have been introduced with the main goals of the research.

\section{Sample}

The research's sample was chosen intentionally. A sample of chosen cases on the basis of extreme situations was chosen. Eight speakers who have recorded alcohol abstinence longer than 10 years participated in the focus group. The longest alcohol abstinence in the speakers was 25 years. The interrogated knew each other through their work in the organization Union of Treated Alcoholics of Croatia.

The research focuses mainly on the experiences and significance of rehabilitated alcoholics, that is, people who have achieved improvement in abstinence during a longer time period through the process of treating alcoholism. The previously mentioned fact represents a lack in which a general opinion about the internalization of alcohol cannot be ex- 
pressed under a subjective consciousness. Regardless, in the spirit of qualitative analysis, this research paper achieves knowledge of an internalized group process of successful alcoholism treatment. Moreover, the meaning of social communities as relevant factors in an alcoholic's decision to undergo treatment can be explored.

\section{Processing and Analysis of Information}

The information gotten from the research was processed by means of logical analysis and mapping topics in specific categories. The information was organized on the basis of so-called Case Production, which unwinds through orientation to critical cases. The substantiality of the research was ensured through a constant review of the theoretical concept of the phenomenology of alcoholism which was used as a platform for the creation of research instruments. Mapping and logical analysis were conducted through defining the framework that makes up the coordinate system of the findings' significance. The lines in the coordinate system of the meaning of our research represent the degree of internalization of functionality of the alcoholic label in a phenomenological sense. Through the focus group, the obtained findings referred to the construction of the coordinate system in four dimensions: encouraging surroundings/conformist surroundings, treating alcoholism as a personal choice/institutional or social coercion to treatment. ${ }^{[12]}$

The first two categories are related to the role of the social factor in encouraging treatment, that is the encouraging environment is related to the social factors that resulted in the decision for treatment. In the research traumatic social experiences that made the addict realize a need for change are also counted in.
The conformist environment in this research presents an environment of high alcoholism tolerance and negating problems inside social reality. The other two categories represent the decision to approach treating alcoholism, that is, which was the dominant factor for going to treatment and the chances of internalizing the alcoholic label and successful treatment in relation to the mentioned factors.

Combining these categories, logical analysis and the processing of information from the focus group, the phenomenological justified conclusions of the relation of individual/social factors towards the process of internalizing the alcoholic label and the process of treating alcoholism can be expressed. With this categorical coding of the research an insight is given into the relationship of individual and collective meaning of alcoholism.

\section{Results}

As shown earlier in the text, the thematic blocks of the semi-structured interview focused on: conversation about the period of discovering the problem, the decision of going to treatment, reflection on the previous state of alcoholism through current experiences, the relationship between society and today's rehabilitated alcoholics. Inside the thematic ensembles a cohesiveness of opinions regarding one's relation to alcoholism and genesis of the decision to go to treatment were achieved. To show the interrelation of factors in revealing the phenomenology of alcoholism more efficiently, a logical matrix in the shape of a coordinate system is presented in Figure 1. The relationship of each factor will be shown through subtitles in which the relationship of the factors will be substantiated with relevant information and 


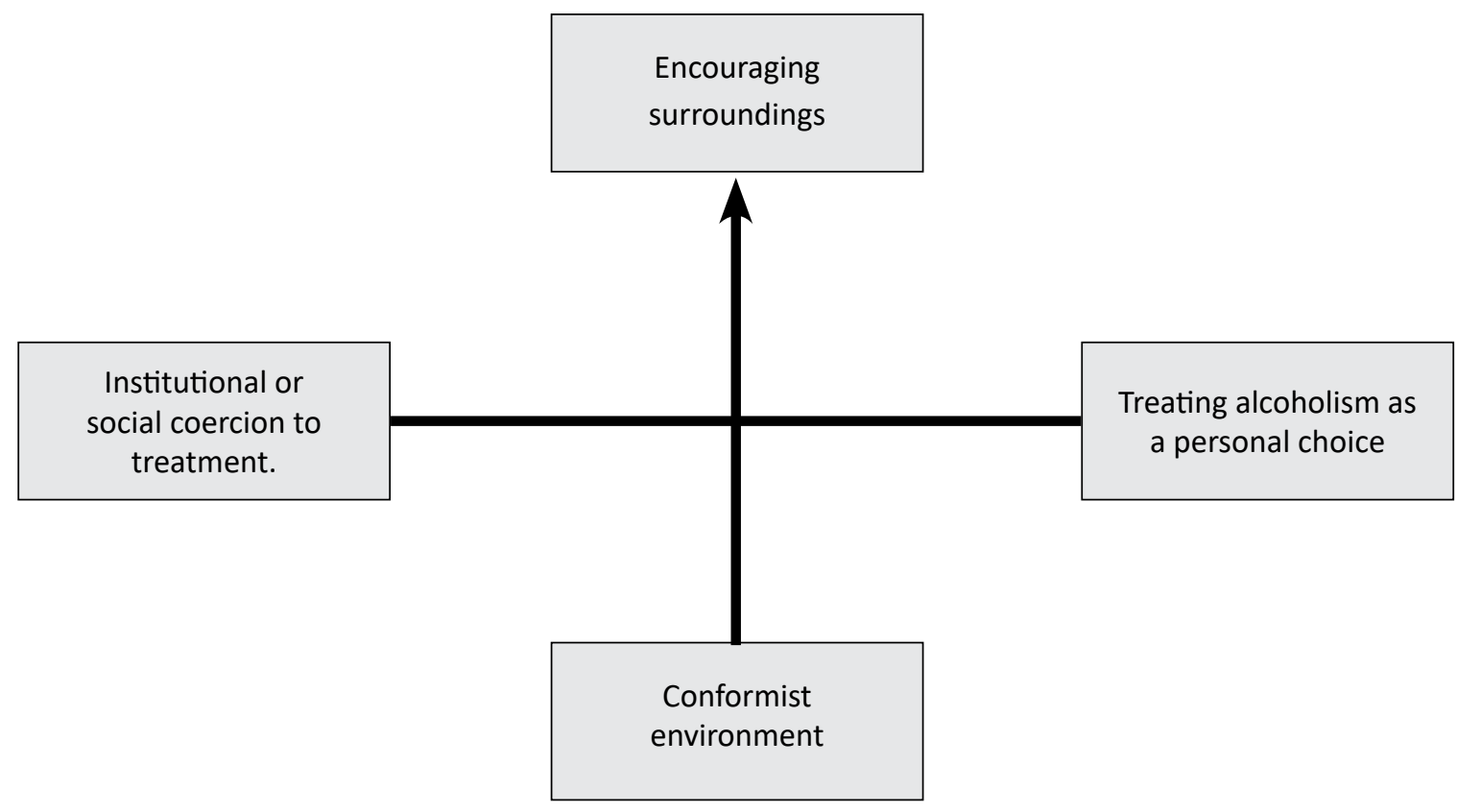

\section{Figure 1.}

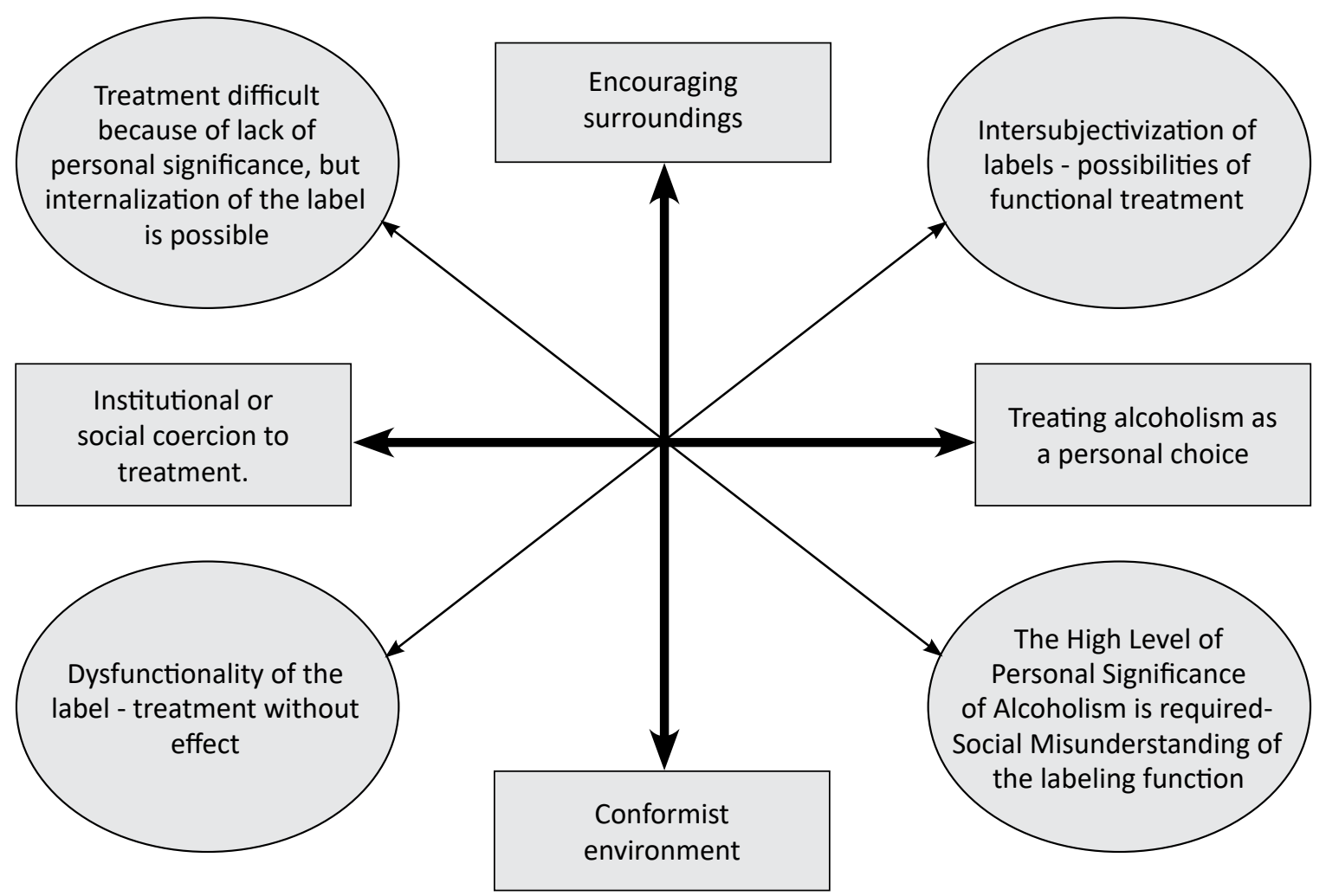

Figure 2. 
excerpts from the transcript from the focus group. The model of the phenomenology of alcoholism is shown in Figure 2.

\section{The Relationship between an Encouraging Environment and a Personal Decision in Treating Alcoholism}

The personal decision to treat alcoholism can be characterised as an internalization of the alcoholic label which is socially convenient. Namely, alcoholism as a label is a complex array of processes that mark individual senselessness and collective dysfunction. However, it should be noted that this type of label is socially convenient, which means it depends on the contextualization of the usage of certain substances (in this case alcohol) in certain communities. The borders of labeling are formed in relation to individual contributions and their involvement in that society's collective rituals. The more alcohol is anchored within the interactive ritual forms of everyday life, the border of labelling is promptly blurred. In this research paper the words "encouraging environment" signify all factors which have encouraged individual questioning of alcoholism. In this case personal labeling can be spoken of. Most examinees reflexively chose to adopt the label of an alcoholic to function in personal social life more efficiently (whether in intimate or structural relationships). An encouraging environment can be both positive and negative, but it is firstly shocking and represents a turning point in one's opinions and construction of sensibility to those who have problems with alcohol.

\footnotetext{
After my mother's death, we drank, played belot and I apparently offended my late mother. However, I do not remember that. When my brothers confirmed it and said what I did I made the decision myself, went to the doctor...
}

and brought up my alcoholism and came to the conclusion that I have to be alcohol's boss, not the other way around. And from that day I have been rehabilitating, for 16 years (G2, (13)).

A participant of the research confirmed his alcoholism through a reflection of his own self on a violation of worth which used to be significant to him. Personal decision did play a key role in this example, however the encouragement for reflection certainly came from a traumatic experience for that individual after an alcoholic phase. The cohesiveness of personal reflection and the decision to go through with treatment connected to an encouraging environment, as shocking as it is, leads to social and individual cohesiveness and a new purpose in community life is created.

When I was getting sober, I woke up thirsty as a dog in 4 o'clock in the morning and went to the bathroom and looked at myself in the mirror. Drops of sweat were going down my face because I had previously drunk about half a litre of water and told myself: you idiot, is that one glass more important than your own life and how much you care for your family and everything? And then I said: alcohol does not exist for you anymore. And my usual personality is: when I promise something, I keep that promise (G2, (13)).

In the second case an encouraging environment can be characterised by reflection on one's own physical state.

When I was 25 I got to Vinogradska in a sleepy state. Now... if that was an alcoholic coma, if I fell from being exhausted, I weighed $104 \mathrm{~kg}$, and then I came to $71 \mathrm{~kg}$. My liver was pitted and I probably just collapsed because of that. That was on the $18^{\text {th }}$ of July, 1992, my first treatment, and to this day I have been abstinent for 25 years with no problems (G4, (13)). 
The significance of the event itself is visible within the fact of remembering the date. Namely, a reflective review of one's own physical state stimulated a personal decision for treatment. From this example it can be observed how the power of an encouraging environment was very great, which resulted in personal reflection and consciousness of the current state of alcoholism as an illness.

\section{The Relationship between Personal Choice and a Conformist Environment}

The next model case shows a state in which personal choice must outweigh the environment's conformist relationship towards alcohol. This case is frequent in societies whose alcohol tolerance is high, and the borders of labelling alcoholism are wide. Environmental conformity can prevent one's reflection towards themselves in sight of increasing alcohol consumption to the point of not being able to undergo treatment anymore. For speaking of treatment processes and the possibilities of rehabilitation in a highly conformist environment to be possible, an immense strength for self-reflection is needed, as well as the ability to review oneself self-critically. A person who decides to go to treatment despite their surroundings has great potential for successful rehabilitation. Anyhow, the first reflective review towards alcoholism in a high tolerance society, though it can only be obtained through hard work. These cases are rarer than the first modelled approach, but the potential for treatment is very high, because of the power of the label's meaning in an individualized sense.

I drank a lot because of the nature of my job and with my friends and my work colleagues. In the end, I felt that it did not have to go on that way. Then I went to my doctor, took directions and came here to Vinogradska. That was in 1972. Although my boss always told me, nothing is wrong with you; I said I know myself! So I was at doctor N/N. Later I got married, got a son, he got a $\mathrm{PbD}$, now he is an assistant professor at Prometni fakultet, he has two children... I went to university and majored in economy and all related to it... I have done a lot for myself and now I am enjoying my pension (G1, (13)).

\section{The Relationship between an Encouraging Environment and Institutional and/or Social Coercion}

An encouraging environment in its positive or negative starting point surely affects an individual's cognition towards alcohol, however encouraging factors don't necessarily generate a successful acceptance of the alcoholic label. The surroundings' encouragement isn't enough for someone to realize their problem and act in the direction of treatment and rehabilitation. However, if the surroundings' encouragement is immense, the social or institutional coercion of labelling an alcoholic gets stronger. Treatment can start with institutional coercion, but the question of efficiency without personal decision still remains unanswered. The approaches towards treating alcoholism can generate an internalization of the label, but the coercion itself does not lead to successful treatment. Still, a positive step in sight of treatment is surely taken with no regards to social/institutional coercion.

One of the participants of the research came to treatment from their social worker's directions, therefore an institutional coercion for treatment was manifested. To accept the alcoholic label, surely time had to have passed in which "spite" regarding preventing failure and new potential negative labels had appeared. To prevent that from happening, 
the alcoholic label was accepted as a means of successful treatment (G5, (13)).

In this modelled case it is important to note how the majority of environmental insight into the problem of alcoholism creates a social reaction and institutionalization of the label for the person to be brought back into the framework of cultural significance.

\section{The Relationship between Coercion and a Conformist Environment}

From the fact that the research was conducted with participants who are rehabilitated alcoholics, the problem of a comprehensive explanation of this modelled relationship comes up. Through the results of the research it is possible to conclude certain indicators of understanding the relationship between institutional coercion and a conformist environment. Namely, through the results of the research a necessity for internalizing the alcoholic label is obvious in sight of successful treatment. If subjective imagery and valorization of the label are left out, treatment would not be possible. On one hand, institutional coercion to treatment in sight of an alcoholic's dysfunction in everyday life and conformist surroundings that negate the problem on the other create a discrepancy in the alcoholic label's meaning. With that alone, an alcoholic can not identify with the label that does not maintain a uniform meaning in the reality of everyday life. In this layout of social and institutional relations, it is very hard to develop an internalized consciousness of the label as a functional generator of alcoholism treatment.

\section{Discussion}

The obtained results of the research indicate the importance of an individual situa- tional frame for determining the meaning of alcohol and alcoholism. The phenomenology of alcohol and alcoholism depends on the subjective creation of its meaning, however it is defined through the reality of everyday life. The framework that determines individual significance of the reality of everyday depends, on one hand, on the stimulants that induce the internalization of the alcoholism label and on the other stimulants that deter an individual from society's constructed acceptance of alcohol. In this research paper the focus on treating alcoholism is put on personal choice and internalizing the alcoholic label as a starting point of rehabilitating from the marginalized collective identity of an individual. The functional relationship between personal choice and the surroundings' encouragement leads to creating an individual meaning of the alcoholic label. The internalization of the label alludes to the return of social sensibility for the individual, considering that the significance of the par excellance reality (the reality of everyday life) is realized once more. The phase of personal choice to undergo treatment is a phase of accepting one's problems on an individual as well as a collective level. The strength of personal decision, that is, the significance of the label, conditions the success of rehabilitation in regards to the phenomenological nature of alcoholism. So far as the reality of everyday life is tolerant towards alcohol and the manifestation of alcoholism, the personal decision to undergo treatment and to implement the label must be more intense. In that sense a discrepancy appears in the consciousness of the individual dysfunction and collective tolerance towards it. The strength of the ritualized power of alcohol in a certain social context assumes a need for a stronger personal decision of accepting the alcoholic 
label. The previously mentioned label in such a social surrounding and context has little to no significance. Significance can be realized individually, by the strength of one's own cognition with the aim of changing one's current individual state. So far as personal motivation and internalization of the alcoholic label's meaning is left out, rehabilitation is much harder to achieve because of lack of sensibility. The sensibility of the alcoholic label must exist in the reality of everyday life as much as it exists in the reality of the individual caught by alcoholism. The internalization of a significant alcoholic label alludes to the return of functionality of a certain society's collective identity basis.

\section{Conclusion}

The aims of this research paper and research focused on exploring the experience and meaning of the alcoholic label for treated alcoholics in the Republic of Croatia. The meaning of the alcoholism label is shown in the rehabilitation process, that is, the treatment of alcoholism. The participants of the research noted in conversation that admitting their problem, that is, accepting the label helped them in facing the illness. Similarly, that same acceptance helped them in rehabilitation. Reintegration in social reality in rehabilitated alcoholics manifested through certain modifications in departures from social norms and ritualized behaviour that tie alcohol to themselves. The model of rehabilitation in regards to the alcoholism label shown in the previous chapters marks the experiences of focus group participants of which all have been abstinent from alcohol for at least ten years. In the model the relationship between individual and collective factors and the success rate of rehabilitation are all shown. The personal decision to undergo treatment and internalization of the alcoholic label in an individual are forced upon as the par excellance condition for treatment. The intensity of this condition surpasses negative environmental and situational factors. The meaning of the alcoholic label in the research participants can be reduced to a common denominator with the capacity to socialize once more. The results of the research in the end note the importance of actors and the possibility of exceeding cultural barriers in "rejecting" alcohol and alcoholism when society is greatly caught up in alcohol tolerance in certain social manifestations. The experience of alcoholism, as previously stated is an experience which the participants remember as a period of senselessness and weakness, as opposed to today's sense and meaning of everyday life that they have created after rehabilitation, after their own confirmation and internalization of the alcoholic label.

\section{Acknowledgements}

None.

\section{Conflicts of interest}

None to declare. 


\section{Reference}

1. Žuškin E, Jukić V, Lipozenčić J, Matošić A, Mustajbegović J, Turčić N, et al. 'Ovisnost o alkoholu - posljedice za zdravlje i radnu sposobnost.' Arhiv za higijenu rada i toksikologiju. 2006;57:413426

2. Brezovec E. 'Consumption of Alcohol in Croatian Social Reality Alcohol as Part of Interaction Ritual Chain', Alcoholism and psychiatry research. 2006; 53: $139-146$

3. Schutz A, Luckmann T. The Structures of the Life-World: Volume 1. Evanston: Northwestern University Press; 1973.

4. Berger PL, Luckmann T. Socijalna konstrukcija zbilje. Zagreb: Naprijed; 1992.

5. Castells M. Moć identiteta. Zagreb: Golden Marketing; 2002.

6. Goffman E. Stigma: Notes on the Management of Spoiled Identity. New York: Simon and Schuster; 2009.
7. Brezovec E, Zoričić Z. 'Socijalni značaj ovisnosti.' in Šta bi sa socijalnom psihijatrijom. Čorić B. ur. Novi Sad: Multidizajn. 2017; 57-64.

8. Mead GH. Um osoba i društvo - sa stajališta socijalnog bihevioralista. Zagreb: Jesenski i Turk; 2003.

9. Natanson M. Phenomenology and Social Sciences: Volume 1. Evanston: Northwestern University Press; 1970.

10. Collins R. 'Sociology: Proscience or Antiscience?' American Sociological Review. 1989; 54: 124-139.

11. Clinard MB, Meier RF. Sociology of Deviant Behaviour: eight edition. Harcourt Brace Jovanovich College Publisher; 1992.

12. Tkalac Verčić A, Sinčić Ćorić D, Pološki Vokić N. Priručnik za metodologiju istraživanja $u$ društvenim djelatnostima - II. Izdanje. Zagreb: M.E.P.; 2004.

13. Brezovec E. Personal interview, 2017.

\section{Fenomenologija etiketiziranja alkoholizma: internalizacija etikete u liječenih alkoholičara u Hrvatskoj}

Sažetak- Ovaj istraživački rad potječe iz fenomenološke analize etiketiranja alkoholizma i njegove individualne internalizacije. Koristeći kvalitativnu metodu fokus grupa, istraženo je značenje i iskustvo etikete alkoholičara u Hrvatskoj. Koristeći model odgovora na liječenje, može se raspravljati o tome kako se značaj etikete ostvaruje u različitim kontekstualnim poveznicama. U modelu se raspravlja o odnosu između osobnog izbora i ohrabrujućeg okruženja, osobnog izbora i prilagodljivog okruženja i nedostatka osobnog izbora s negativnim prefiksom na okolišne čimbenike. Osnovna polazna točka ovog rada leži u hipotezama postojanja par excellance stvarnosti, stvarnosti svakodnevnog života i oblika stvarnosti koji su vezani uz njega. Međutim, pojedinac situacijski procjenjuje značaj tih obrazaca i karakteristično ih internalizira. lako ima fenomenološku analizu u svojem korijenu, ovaj rad karakterizira dualnost strukture i djelovanja u vezi s etiketom alkoholizma. Pretpostavljena realnost svakodnevnog života i njezin odnos s alkoholizmom nisu dovoljni za društvenu funkcionalnost etikete alkoholičara. Subjektivizacija, odnosno, internalizacija etikete potrebna je kako bi se postigla svrha i značenje.

Ključne riječi: etiketa, alkoholizam, liječeni alkoholičari, Hrvatska, fenomenologija 
